\title{
Ethical foundations in sustainable fashion
}

\author{
Kirsi Niinimäki
}

\begin{abstract}
Sustainability is fuzzy and wide concept and the discussion what to sustain continues, the resources or lifestyle. Furthermore how holistically the sustainability should be approached is under discussion. According to the holistic approach for environmental ethics ecosystems and biosphere as a whole should be considered, not individual's rights. Furthermore in ethical discussion the value aspect is most important; what is considered to be valuable and from where value comes from. Furthermore environmental ethics raises deep questions; who counts morally and why. Moreover the human actions are under evaluation in environmental ethical discussion; "how should human beings act in the nonhuman natural world".

Environmental ethics can be applied in other fields e.g. in design and fashion. Values and ethics are fundamental grounds also for sustainable fashion. Environmental pioneer 1995 argues that "ethics are the philosophical basis for making choices about morals and values". He further continues that "to think dispassionately about what we design and why, and what the eventual consequences of our design intervention may be, is the basis of ethical thinking". Accordingly it is worthwhile to investigate the value base in sustainable fashion and further to consider the consequences of our design and industrial manufacturing processes in the clothing sector based on environmental ethics. Moreover it is important to understand the consequences of our design practices; e.g. how current design, manufacturing and business practices affect unsustainable consumption patterns. Products actually configure consumers' needs and use patterns and hence design can be said to be "practice-oriented", which leads to certain everyday consumption habits. Therefore designers, manufacturers and companies are responsible not only for the environmental impacts of the fashion industry but also for the unsustainable consumption behaviour of consumers and the increase of waste streams, i.e. the unbalance in the fashion system.

This text provides an overview for ethical foundations in the fashion field. Even though a lot of research has been done lately in the sustainable fashion field, the views have been limited and not well grounded on philosophical knowledge about environmental ethics and value discussion.
\end{abstract}

Keywords: Environmental ethics; Values; Sustainable fashion; Corporate social responsibility (CSR); Ethical consumption; Extended producer responsibility (EPR); Sustainable business; Greenwashing

\section{Introduction}

Sustainability is fuzzy and wide concept and the discussion what to sustain continues, the resources or lifestyle. Furthermore how holistically the sustainability should be approached and understood is under discussion (e.g. Scherer 2003, 355). According to the holistic approach for environmental ethics ecosystems and biosphere as a whole should be considered, not individual's rights (Palmer 2003). Furthermore in ethical discussion the value aspect is most important; what is considered to be valuable and from

Correspondence: kirsi.niinimaki@aalto.fi

Design department, School of Arts, Design and Architecture, Aalto University, PO Box 31000, FI-00076 Aalto, Finland where value comes from (ibid.). In addition environmental ethics raises deep questions; who counts morally and why. According to Palmer (2003) firstly the community, rather than individual should be in the focus while evaluating moral significance. Secondly ecological qualities have primary value. Moreover the human actions are under evaluation in environmental ethical discussion; "how should human beings act in the nonhuman natural world" (ibid. 17).

This text provides an overview for ethical foundations in the fashion field. Even though a lot of research has been done lately in the sustainable fashion field, the views and research approaches have been limited and not well grounded on philosophical knowledge about

\section{Springer}


environmental ethics and value discussion. Interesting research is emerging mainly in the small niche areas about sustainable fashion, its meaning and connection to use phase and individual consumer's needs and participation (e.g. Fletcher 2008; Fletcher and Grose 2012), but in fore mentioned the focus has been mainly on a small and design-driven initiatives. This text focuses on the change in the industrial scale.

This text is based on author's earlier writings extended with other experts' views of values in the sustainable fashion field. This knowledge is reflected against environmental ethics. The text starts by reviewing environmental ethics and the current discussion going on in the sustainable fashion field. Thereafter new business thinking in the context of sustainability, innovation for sustainable business, future oriented thinking, collaboration with the customer, CSR, EPR, animal ethics and ethical luxury is presented. Moreover the text discusses about greenwashing and ethical consumption. The text ends with the consideration how to design value.

\section{Review}

Environmental ethics can be applied in other fields (Light and Rolston III 2003) e.g. in design and fashion. Values and ethics are fundamental grounds for sustainable design. Environmental pioneer Viktor Papanek $(1995,70)$ argues that "ethics are the philosophical basis for making choices about morals and values". He further continues that "to think dispassionately about what we design and why, and what the eventual consequences of our design intervention may be, is the basis of ethical thinking" (ibid.). Therefore ethical thinking takes account the moral implications of our actions (Clegg 2011). Accordingly it is worthwhile to investigate the value base in sustainable fashion and further to consider the consequences of our design and industrial manufacturing processes have in the context of sustainable development.

It would be fruitful for designers to consider whose values are included in the design process and on what basis. It is also good to remember that there isn't any value-free design. We should design and construct a new system and basis for value creation, to help us face future challenges in the fashion discipline. Such a system could serve to evaluate design proposals and their benefits for sustainable development in a long term. Furthermore manufacturing processes, business models and marketing ethics could be included in this value evaluation process. However we need novel knowledge on how to embed the dimension of environmental value and future-oriented thinking into the current fashion system.
While including the ethical dimensions in the sustainability discussion, we have to start the discussion from values. Values relate to beliefs about good and bad, right and wrong, and they are the basis that gives direction to our moral behavior (e.g. Gibbins and Reimar 1999). Paehike (2000) has listed the core values in environmentalism: firstly, the protection of biodiversity and ecological systems; secondly, consideration of negative impacts on human health; and finally the sustainable use of resources. Moreover he argues that these values are not sufficient, and we must challenge our whole way of living: how we organize our societies and how we live our lives, including new challenges in purchasing and use patterns and in disposal behavior (ibid.).

Leiserowitz, Kates and Parris (2006) argue that the most important value in sustainable development is environmental protection. This is a very broad concept and includes many different values and approaches. In addition to environmental protection, in sustainable development there are three key 'stakeholders': people, the economy and society, whose sustainable development also needs to be taken care of in the quest to achieve a sustainable balance in the system. In this process values such as equality, freedom, and democracy are most important (ibid.).

Walker $(2007,70)$ argues that in the context of sustainable development it is possible to add ideological value to objects. This means that through environmental values we can assess products in a completely new way. Through this lens it is possible to value e.g. redesigned objects according to their environmental value. Accordingly eco-materials, leftover materials, recycled products and parts, and a 'classical' appearance can be evaluated with the goal of increasing the environmental and sustainable value of the product. Moreover renting, leasing and other actions aiming to dematerialize consumption can be seen as sustainable value actions (Niinimäki 2011).

The ethical and value discussion is complex and hard to do in the industrial context. As today it seems that possibilities in industry to make ecological and ethical choices are limited, designers and producers do what they can, a situation that can be described as realistic thinking. This kind of value-based, yet realistic but narrow, approach to sustainable fashion is the most common approach currently existing in the business. Best practice can be defined to mean that designers and companies choose the best environmental and social solution that exists (Niinimäki 2013). Especially small- and medium-sized companies have to make their choices from limited possibilities. Finding suitable eco-materials that can be ordered in small amounts, to give only one example, can be most challenging for small companies (Niinimäki and Aakko 2014). What an entrepreneur can do is thus limited and defined by the resources available as well as based on the current 
rather narrow knowledge base. Accordingly available resources create the action framework for sustainable-oriented designers and companies: i.e. what kinds of design and production choices they can make. The bigger the fashion company, the more power and possibilities they have to influence sustainable practices in the field. Despite these limitations, it is important that designers and companies identify their own value base, act accordingly, and inform their customers about their values and ethical actions (Niinimäki 2013).

\section{New business thinking in the context of sustainability}

New radical business thinking is needed to create a bigger change in the fashion field. The economic and industrial systems of the fashion industry are currently based on extremely fast cycles of production, fast-changing trends and planned obsolescence of the products. As garment prices fall, producers must maintain profitability by increasing the amount of sold units, which has led to a huge amount of fashion products on the market and extremely saturated markets (Niinimäki 2011; 2013). We must find new radical ways to create a win-win situation for both consumers and manufacturers - for all stakeholders - and for sustainable development. We need more knowledge about consumers and the consumption side to create a sustainable transformation process inside the fashion industry and business that leads to sustainable consumption practices. We also need to develop foresight and new systemic thinking on how to move towards sustainable societies, in order to see sustainable practices as an opportunity to design and not to think that sustainability is an obstacle to doing business. Very often, the sustainable business approach is feared to mean de-growth, but it can also be seen as a new challenge and opportunity to do things creatively and differently (Niinimäki 2013). Sustainable business logic is based on fundamentally different logic than traditional fashion business and not on the growth logic alone (Fletcher and Grose 2012).

Sustainable values lay the ground for credible and responsible sustainable business and marketing. Sustainable business and marketing includes not only a sustainable value base but also ethical consideration. This aspect seems to be problematic for some manufacturers and companies, they do not want to make moral claims about what is right and what is wrong. However, for strategic sustainability thinking, it is important to consider not only what efforts and investments to make but if would it be worthwhile to withdraw from some markets because of ethical reasons or too big social or ecological risks (Belz and Peattie 2011). In this regard, a deep assessment should be made according to the company's own value base. Including sustainability in the company's strategic planning might open new strategic possibilities but it can also be done to prevent risks in legal, resource, environmental, reputational or sociopolitical levels (Lowitt 2011).

As the fashion industry is international and global, principles of corporate social responsibility (CSR) should be followed. Moreover, it is important to remember that consumers' trust can only be achieved through open communication and information and only through real commitment to sustainability at all levels of the company's practices, avoiding too limited a sustainable approach and a 'greenwashing' attitude. In addition, because of the global character of the fashion business, the attribute 'Made in' is today less relevant than the attribute 'Made by', which needs a lot of information gathering about the different stages in manufacturing and communicating these aspects not only to consumers but also to all stakeholders.

Stakeholders in sustainable marketing thinking are not only consumers and investors but can also include employees, business partners, suppliers, competitors, government (through regulations), NGOs, pressure groups and communities. Working with these stakeholders needs consideration of not only exchanges but also long-term relationships and future possibilities through radical sustainable innovations (Belz and Peattie 2011).

The global fashion business is fiercely competitive, and simultaneously, Western consumers' environmental interest is increasing; in this environment, sustainable business thinking and sustainable marketing offer new business opportunities for the fashion industry. As it is challenging to ensure profit with the existing fashion system and current price levels, it is worthwhile to challenge the current unsustainable business models in fashion and rethink value creation from a wider perspective: value proposals from the consumers' side as well as from the environmental perspective and through creating long-term relationships between business and its stakeholders (Niinimäki 2013). In this context, it is possible to create sustainable value proposals and stimulate new business thinking and business models that contribute to a decrease in materialistic consumption.

\section{Innovation for sustainable business}

Vezzoli (2007) argues that radical innovations are needed which do not only depend on technological development and innovations but also stimulate new interaction and partnerships between different stakeholders as well as new sustainable relationships between consumers and products. If we want to change the fashion system towards a new kind of balance, we need new kinds of radical design and business thinking. We have to change the current economic paradigm, and we have to do business differently than we do today. Business and industry have to redefine their tasks more radically in order to usher in significant eco-innovations and most importantly allnew business strategies (Ottoman 2011, 90). As Kemp 
(2008) reports, a fundamental change is needed to reach systemic change, but transition faces resistance and it takes time to emerge. On the other hand, system level changes can be based on paradigms, understanding how ideas relate to each other to form accepted models (Fletcher 2008, 73, based on Meadows 1997). As Fletcher $(2008,71)$ argues 'if we influence things at the level of a paradigm, then a system can be totally transformed'. This system level transformation needs questioning current practices and understanding, and further, it needs a new way of seeing and understanding.

When we talk about eco-innovations, we mean products, services or processes that offer value not only for both the business and customer but also to the environment through significant decrease in environmental impact. Sustainable innovation is a larger systemic approach where sustainability thinking is integrated in all levels of the business (products, technologies, services, new business models, organisation model and relationship with stakeholders) (Niinimäki 2013).

The levels of innovation are described as follows (based on Brezet and van Hemel 1997):

(1) Incremental (small improvements for existing products)

(2) Redesign (major redesign for existing products)

(3) Product alternatives (new product or service concepts)

(4) System innovation and design for a sustainable society

The first level of innovation refers to small, incremental product improvements. The second means redesigning existing products and production processes (e.g. in an eco-efficient way), and the third innovation type aims to find alternative methods of delivering the same function (Brezet and van Hemel 1997). Currently, our efforts in sustainable fashion are between the second and third levels. However, these innovation types are not enough, and we need to move towards more radical and systematic innovative thinking while challenging the whole industry and its current practices of doing business.

Tischner and Charter (2001) identify four approaches to sustainable design: repair, refine, redesign and rethink. The fourth approach is the one we should aim for and close to the forementioned system level innovation. A rethink requires a radical change in our mind set, and it can offer breakthroughs for new lifestyles, ways of living and doing things, as well as approaches to fulfil consumer needs in a more sustainable manner (Tischner and Charter 2001). This approach needs strategic innovations that lead to new business models. As Tukker et al. (2008) argue, these new practices often stay in niches for a long period until a window of opportunity opens and their breakthrough is possible.

For this radical and strategic innovation approach, we need a much more creative way of conducting the business of fashion. Strategic innovation questions who the customer is, what products or services should be offered and how to offer those products and services (Markides 1997). It is not merely about rethinking the fundamentals on the supply side but also about redesigning the business on the demand side, e.g. in the form of the user experience and rethinking value creation moving from product design to systems thinking (e.g. designing product-service systems) or designing products for closed loop system.

Several companies acknowledge that market competition is driven by products' meanings: 'why' people need a product rather than 'what' they need in a product. As Verganti (2009) argues, people use things for profound emotional, psychological and sociocultural reasons as well as utilitarian ones, and this understanding is most important in creating successful sustainable innovations for business. This deep understanding of consumers also lays the ground for transforming business models and creating for example sustainable product-service systems to fulfil the actual needs behind product use in a less materialistic way (e.g. Armstrong et al. 2015).

Innovations for sustainable business in the textile and fashion sector can be driven by technological improvements or technological innovations (like digital technology), economic changes (new sustainable business thinking and a systems approach) or legislation. With regard to legislation, new regulations for extended producer responsibility (EPR), for example, can change the logic in the fashion system, and preventing and/or recycling waste might be one future business model if EPR begins to cover the textile and fashion business. Innovation can also be driven by more abstract value issues, e.g. safeguarding the corporate or brand value from a bad reputation.

Succeeding in innovation in the sustainability context always needs a new kind of business logic. Driving sustainable innovation, whether to a more radical or incremental path, needs experimental and creative thinking, and this experimentation can get support from lead users before presenting these ideas to all customers. Furthermore, it is important to create networks of sustainable-oriented companies. These networks can support a company's own values-based practices and offer help in reaching their goals.

\section{Future-oriented thinking and collaboration with customers}

New kinds of relationships with the customer create new kinds of value in the business. Through a deeper relationship with the customer, a company can create a long-term dialogue with the end-user and through this dialogue create new business opportunities, new understanding of the customer's true needs and desires and robust understanding of the customer's readiness to change consumption habits. Simultaneously, the company can communicate its 
values and practices to customers and thereby create trust and customer loyalty towards the brand.

Through this approach, the company's focus moves from a single transaction and short-term economic thinking to long-term sustainable strategic planning and future-oriented thinking. Customer satisfaction and customer value will be at the core of the company's practices. Traditional marketing focuses on profit and revenues. Sustainable marketing also concentrates on psychographic aspects like consumer satisfaction and consumers' interest to stay loyal to the brand (Belz and Peattie 2011).

New business approaches are possible, but they require radical business thinking, focus on the consumer side and the garment's use phase and, most of all, consumer satisfaction issues. According to Manzini (1994), to change the system towards sustainability, it is not enough to redesign existing products and make some eco-efficiency improvements in manufacturing processes if the aim is to reach a more sustainable future. Eco-efficiency aims to decrease the environmental impact of industry while simultaneously using less material while manufacturing more products and resulting in less waste. The eco-efficiency approach also means savings in material, energy and chemical costs and waste disposal costs (Niinimäki 2011).

On the other hand, by taking consumer-based ecoefficiency into account, it is possible to open up opportunities for the fashion business that aim for sustainable consumption patterns. Hence, consumer-based eco-efficiency thinking in business can transform the fashion system towards re-directive practices that aim for deeper consumer satisfaction and therefore sustainable consumption patterns. Consumer-based eco-efficiency focuses not only on the environmental impact of the use phase but also on product quality and consumer satisfaction issues (Park and Tahara 2008; Niinimäki 2014). Through the satisfaction approach, value can be created for the consumer, the company and even the environment. Satisfied customers use products longer, and this is an opportunity to decrease the amount of purchased clothing and slow down consumption. This is a value opportunity from the environmental viewpoint. Satisfied consumers are loyal customers, and they repeat their purchase behaviour and continue buying brands that can provide them with product satisfaction on many levels, and this is a value opportunity for sustainable business (Niinimäki 2014).

\section{Ethicality in production and CSR}

In today's reality in the fashion field, more and more garments are manufactured in other countries, very often on the other side of the globe. About $80 \%$ of clothing exports are shipped from undeveloped countries to developed economies. For example, in Finland, about $90 \%$ of sold garments are imported from Asian and Far East countries, about 5\% from
European Union (EU) and other countries, and only about $5 \%$ are manufactured in Finland. In this fragmented and globalised supply network, the main issue is risk management. From the recent accidents and fires in Bangladeshi textile factories, we know that the lack of awareness about the weak points in the supply chain creates a reputational risk, at the very least. CSR tackles these issues: i.e. what enterprises' responsibilities are regarding their impacts on society. Additionally, corporations should integrate social, environmental, ethical human rights and consumer concerns into their strategy in cooperation with their stakeholders. Corporate social responsibility is used in parallel with the terms corporate citizenship, corporate responsibility and corporate sustainability (Niinimäki 2013).

If the producer wants to address sustainability issues in the supply chain to a greater extent, it is important to select subcontractors well and demand good practices. The code of conduct principles help companies in this process, and standards like SA 8000, ISO 14001 and Eco-Management and Audit Scheme (EMAS) help when considering environmental and social aspects in design and manufacturing practices. Additionally, the UN has defined ten principles called the 'Global Compact' to set standards for subcontractors (https://www.unglobalcompact.org/abouttheGC/thetenprinciples/index.html). These principles take account of issues from human rights, labour issues, environment initiatives and issues in anti-corruption. Several companies have voluntarily accepted these principles and follow them in their own subcontracting arrangements, for example, Puma, GAP and Nike. Checklists exist where producers can pick requirements for their subcontractors (e.g. http://www.csrcompass.com/).

Better than just giving the code of conduct list to manufacturers is to work in collaboration to improve the situation. Working with subcontractors and establishing a tight relationship, mutual understanding and trust take time. The producer's goals and requirements in sustainability have to be well communicated and preferably based on mutual motivation. Furthermore, to build motivation, it is uplifting to show successful examples of how to work with sustainability in the fashion field (Kruger et al. 2012).

Companies can benefit and gain great advantages by using charity or donation in their CSR strategies. The charity work should be rooted in the companies' actions strategically so that it engenders long-term business opportunities and improves the competitive surroundings through charity...' (Porter and Kramer 2006, as cited by Kruger et al. 2012, p. 15). It is important to realise that acting responsibly and promoting CSR do not necessarily mean direct revenues to the company. The motivation to act responsibly is based on values other than economic but actions might also be (or should be) economically successful in the long run. 
The sustainability strategies should also be included at all levels inside the company. All departments should commit to sustainability practices, and all processes and products should include sustainability principles. Furthermore, the sustainability of business is the most important, so the business must be profitable. It is also important to understand that sustainability and CSR needs constant evaluation; therefore, it is a constant commitment and learning process for the company (van Dyk 2008).

\section{EPR extended producer responsibility}

Recently, the approach of extended producer responsibility (EPR) has gained a lot of attention and discussion in the EU. Extended producer responsibility requires the original manufacturer or producer to take back the product after its use. In EPR, the goal is that already in the design phase producers think about and plan how they can reduce environmental impact of the product after its use. This post-consumer waste should be reused, redesigned or recycled. In this concept, companies are forced to have a waste management system and preferably take-back systems based on closed or open loop thinking, or, if not, pay waste treatment costs. Closed loop thinking means that all off-cuts, waste and products after their use time are treated inside the factory's own processes, and open loop means that leftovers are handled by some other outside partner (Niinimäki 2013; Belz and Peattie 2011). The principle is familiar in, e.g. electronic products but not yet in textiles.

EPR does not yet cover the fashion and textile field but it soon might, and this would change fashion companies' action logic, as old garments mean extra cost through waste treatment. EU policy aims for waste prevention, closing landfills and effective material recycling systems already in year 2016. This would also cover textiles and fashion. Right now, textile waste ends up in landfills or as energy waste in most European countries. France is one exception. There producers, distributors and importers of clothes, linen and footwear have had to take back old products since 2008. A company has to have a take-back system itself or it can join a scheme, which is accredited by the French government, and pay into it (right now EcoTLC) (Tojo et al. 2012).

Extended producer responsibility is a good example how to transform the business and industry and how to include the environmental values in the business logic. It is an example of environmental ethics: how we should take responsibility of our actions and take account the consequences of our industrial manufacturing and business logic.

\section{Animal ethics and ethical luxury}

Animal ethics are largely discussed in the fashion field, yet the issue is controversial. This discussion needs philosophical foundation. The moral discussion, whether it is morally right or wrong to mistreat animals, has a long history in environmental ethics, longer than any other ethical discussion. Already, Immanuel Kant and St. Thomas Aquinas in the eighteenth century argued that it is morally wrong to harm animals, simultaneously arguing that animals deserve moral recognition (Light and Rolston 2003). Contemporary philosophy 'Animal Rights View Ethics' (also known as intentional ethics) points out that each individual (human or animal) has rights that should not be violated, and therefore, 'living creatures must never be used exclusively as a means to others' satisfaction' (Kruger et al. 2012,133). On the other hand, 'necessary ethics' or 'utilitarian ethics' emphasises that there has to be a balance in the sum of individual's utility/happiness/quality of life, and therefore, animals can be used in industrial production but the animals' living situation has to be evaluated based on the aforementioned balance also in the industrial production (ibid.). In the code of conduct by the Trade Association Dansk Fashion and Textile is stated following: 'in businesses where animals are used in labour and/or in the production (fur, wool, etc.), such animals must be fed and treated with dignity and respect and no animal must deliberately be harmed nor exposed to pain in their lifespan' (Kruger et al. 2012, 135).

Animal products are used in wool, silk, feather, leather and fur production. Large-scale industrial production causes ethical problems through animals' living condition and, e.g. while plucking feathers from live ducks and killing silkworms during silk production. Wool is a renewable material and therefore good for the environment, but practices in the wool production cause ethical problems, e.g. 'mulesing', practised in Australia, causes unnecessary pain for sheep. In 'mulesing', some skin is removed from the sheep's tail and breech to prevent 'flystrike' (Black 2011, 136).

Some animal materials such as leather come as leftovers from food production, and this can be seen as a valuable and sustainable resource in the fashion industry. On the other hand, fur farms are considered as unethical practices in many countries, and they raise much discussion and counterreactions among stakeholders because of the animal welfare. Even though circumstances on the fur farms are improved, discussion on ethics and animal rights is continuing. Nevertheless, clothes made from fur are expensive, valuable, durable and long-lasting, and they need little maintenance during use. Very often, fur coats are passed on for generations, which make these items connect with fond memories, and emotional attachment may easily form to these kinds of special possessions. It is also possible to redesign old fur clothes with highquality manufacturing processes so they look new. Therefore, durable and long-lasting fur is a potentially sustainable alternative (Niinimäki 2013). 
WILD Concept by Marita Huurinainen offers one sustainable way to find other fur resources than farmed ones. WILD Concept's furs come from animals that have been hunted in the wilderness. In Finland, many thousands of animals need to be shot every year to maintain balance in the ecosystem, especially to protect other animal populations, and normally, these carcasses are disposed of as waste. The important issue is that no extra pain is caused to animals during the hunting (e.g. avoiding foot-hold traps). The fur used for WILD Concept is bought directly from registered Finnish hunters who hunt the animals within the quotas allowed by the government. The wild origin of the furs is assured by the Wild Finnish Fur label. Together with the Wild Finnish Fur Association (Luonnonturkisyhdistys), designer Huurinainen has developed this alternative fur concept in order to prevent hunted animal carcasses ending up as waste. It can be guaranteed that the animals used for the WILD concept have not suffered to become a clothing item. What makes WILD unique is that it offers an ethical and responsible way to wear fur, as fur of farmed animals is not used. The end result is ethical luxury (Niinimäki 2013). Ethical luxury can be defined to mean something which is produced according to sustainable and ethical principles, which has a high environmental, intrinsic and aesthetic value, it is high quality, durable and long lasting. Ethical luxury is produced in slower processes and in small quantities, ending up in unique pieces or limited edition. Its high aesthetic and monetary value makes it valuable and long lasting, something to fall in love with; maintain it well, perhaps update it and pass on for the next generation.

\section{Ethical and transparent}

Since global manufacturing systems are complex, transparency is an important issue in the sustainable fashion field. Publishing all information from the supply chain, the names and locations of the suppliers and subcontracting partners sends a positive message; and therefore, transparency can build consumers' trust. An encouraging example of this practice is the company Patagonia, which has been a leader in supply chain transparency for many years. Patagonia has set sustainability principles as a core in their strategy. The company offers not only information about all its manufacturing locations worldwide but also background information about the factories they are collaborating with, as well as general environmental and social information about global manufacturing. Consumers can find all this information in Patagonia's webpages.

In the global fashion business, it has become challenging to identify the origin of a product since production processes are fragmented into several countries, and supply chains are complex. Yet, this information is valuable for consumers, and more transparency is demanded especially in clothing manufacturing. The 'Made by' label is based in the Netherlands, and its goal is transparency in clothing manufacturing. Through 'Made by' system, it is possible to trace the manufacturer of a garment through a code and the use of the internet (Fletcher 2008, 68).

According to the principles of transparency, a company can inform its sustainable and ethical actions, yet all information has to be true and objective, even the negative aspects should be informed or which efforts have not yet ended in good results. Transparency should not be only positive marketing message, or it changes to marketing ethos only and easily turns to greenwashing.

\section{Greenwashing}

Because Western consumers' environmental interest is rising, companies may be tempted to use sustainable and environmental arguments merely to increase sales. And because environmental and sustainability issues are complex, it is also easy to mislead consumers. Companies can use sustainability as a "marketing ploy" (Goworek et al. 2013,388 ) - something that can be seen as greenwashing.

To avoid greenwashing, too narrow a focus on environmental issues should be avoided and a more holistic understanding is needed. For example, if a fast-fashion company uses eco-labels on some of its products or one product line, it does not truly change the fashion system or the economic logic behind it; the company's environmental load is still huge since it produces too much stuff in extremely fast cycles. A similar example is where a fastfashion company uses paper bags instead of plastic ones. The business logic does not change with this small detail. The company's values have to be grounded deeply in sustainability, and its principles should be included and implemented substantially at all levels and functions.

The other aspect to consider is that all information about the environmental benefits of the product has to be proven. In this regard, standardised eco-labels are much better than the company's own environmental statements. Eco-labels (certificates) are based on an independent organisation's tests and evaluation criteria and are thus more objective and reliable than the company's own information. All irrelevant or confusing information should also be avoided.

\section{Ethical consumption}

One of the most important factors in the environmental impact during the use phase is the garment's lifetime. Currently, garments are far cheaper compared to household incomes than a few decades ago (Niinimäki 2011). According to Jackson and Shaw $(2009,146)$, in the 1950 s in the UK, $30 \%$ of a household's income went to clothing purchases; currently, that figure is $12 \%$, with a higher amount of consumed items. At the beginning of the twenty-first century, e.g. in the UK, fashion consumption increased by one third (Allwood et al. 2006, 11), and this was a tendency in all Western countries especially between years 1995 and 
2005 (Niinimäki 2011). It is also estimated that even if the total amount of textile and clothing purchasing is growing, clothing will form a decreasing proportion of households' total spending because of falling prices. Due to these low prices and households' high incomes, the consumption of extremely cheap and disposable fashion with a very short life span has increased (Jackson and Shaw 2009). Textile and clothing prices have fallen, and currently, the consumer possesses more and more impulsebuy cheap garments and low-quality textiles (Niinimäki 2011). These kinds of low-quality and cheap garments are easy to discard. Therefore, extending the life span of garments is one of the most critical issues for sustainable development.

In the UK, a study showed that almost half of people's clothes have sat in a closet without being used during the last twelve-month period. It is estimated that this means 2.4 billion items in the UK alone. And most of these unused clothes are owned by young consumers aged 25 to 34 years (Belz and Peattie 2011, p. 125). Another study from the Netherlands showed that the average piece of clothing is owned for 3 years and 5 months. During that time, it is worn for only 44 days (Uitdenbogerd 1998, as cited by Fletcher 2008). These figures show that all Western consumers pose too many clothing items and use them too seldom before disposing them.

Contrary to the current system, product durability and long-term use are prerequisites for sustainable consumption (Cooper 2005). To slow down consumption, it is important to invest in high quality and durability as well as in aesthetically ageing materials, high design and lasting style. In this regard, services that aim to extend how long garments are used offer value in the sustainable development context (Niinimäki 2014). One challenge in the current system is how to design products added with services that encourage consumers to adopt a more environmentally responsible behaviour.

When focusing on ethical and sustainable use and consumption, the following issues should be considered (Niinimäki 2013):

- -Purchasing fewer garments

- - Investing in meaningful garments (promoting emotional bonding)

- -Investing in durable garments, more classical style and high quality

- - Investing in eco-materials and eco-labels

- -Extending garments' owning time and using them more frequently

- -Washing less, letting garments rest and air between use

- -Maintaining garments, also repairing

- -Using services to intensify use and to extend the use time (e.g. repair, upgrading) (Niinimäki 2013).
Consumption and consumerism lie at the core of Western societies. Consumption is an important function in people's everyday life. Current consumption patterns are strongly connected to industrial manufacturing systems, economic systems and the underlying economic values supporting this unsustainable system. Consumption and purchasing situations often involve a strong emotional experience for consumers. Therefore, we should also create systems that offer other kinds of emotional experiences and satisfaction than from buying new fashion items. This could happen for example through strategically sustainable design that includes services (Niinimäki 2011).

\section{Designing value}

Ehrenfeld (2015) points out that conventional actions in sustainable fashion can at best only slow down the destruction, not save the Earth. According to him, current actions in the industry do not create sustainability, they only reduce unsustainability. He claims that concentrating in, e.g. technical eco-efficiency improvements, CSR or eco-materials only fool the designers, manufacturers and consumers into believing that they are doing all it takes to create sustainability-as-flourishing (ibid., 59). Ehrenfeld (2015) defines sustainability-as-flourishing to mean a normative approach to sustain human beings and ecosystems on the planet forever. In this approach, it should be named what has to sustain. Without naming the elements to be sustained, sustainability is an empty word according to him. To be more influential, sustainable fashion industry has to focus on transforming underlying beliefs and values that currently maintain unsustainable practices in the system level. Design system has to change the beliefs on caring, instead of needing in sustainabilityas-flourishing approach. In here, the project 'Local Wisdom' which concentrates on the use phase of clothing and the craft of use is a good example. The project collects user experiences: tending, fixing and satisfying the use of garments in a long term, and it frames the design and use as a single whole and uses the use practices into design thinking, bringing the creative use practices into designers' reality (Flecther 2015). As Fletcher (2008) argues in a more holistic approach to sustainability, the design aesthetic has to be grounded on long-term sustainability and values in it.

Design forms an integral part of our culture and values within. This means that sustainable design should not only take into account environmental values but cultural, social, ethical and economic values should also be included in the sustainable design process (e.g. Tischner and Charter 2001). Designing could change and become a more proactive and participatory process aiming for aesthetic sustainability (Niemelä 2010, 60). To this ambition, it can be added that sustainable design can also be a proactive process that aims to transform consumption patterns 
towards more sustainable ones, and therefore, it includes future-oriented thinking and future-oriented value (Niinimäki 2011). It is important to understand how the current design, manufacturing and business practices affect unsustainable consumption patterns. Products actually configure consumers' needs and use patterns, and hence, design can be said to be 'practiceoriented', which leads to certain everyday consumption habits (Shove et al. 2007, 134-136). Therefore, designers, manufacturers and companies are responsible not only for the environmental impacts of the fashion industry but also for the unsustainable consumption behaviour of consumers and the increase of waste streams.

Designers can even destroy the value of the product by creating fast-changing trends that quickly outdate the products and render them valueless. The product itself may destroy something valuable, such as a craft skill or local knowledge (Fry 2009), something we already have seen in the area of fashion: manufacturing locations are far from end markets, and local manufacturing skills have diminished or disappeared. At the same time, only few consumers can repair their own garments or have skills to create garments themselves; many do not even own a sewing machine (Niinimäki 2011; Armstrong et al. 2015). Thinking about what we design and produce and why, as well as what consequences our design may bring, forms the basis of ethical thinking and future-oriented value creation.

Future-oriented value creation as an approach guides designers and manufacturers towards far-sighted products and far-sighted business thinking, transforming current practices towards more sustainable societies. Each design and manufacturing decision has to include consideration of the future: how the product will be used, how it will age, how it will be disposed of and what environmental impact the product will have (during manufacturing, use and after use). Furthermore, the business model and its influence on consumption practices are included in this evaluation process (e.g. a slow system versus a fast system). What consequences do the product and its manufacturing have with regard to environmental, societal and cultural values? All these aspects have to be considered before the product is designed or manufactured. And is there the possibility to completely avoid materialistic consumption and do business differently? Radical thinking (e.g. a PSS approach to fulfil consumers' needs in a de-materialistic way) is needed to create a new value creation process in sustainable fashion (Armstrong et al. 2015).

At best, a new kind of sustainable fashion system can create value for people, planet and profit (see Figure 1). For people, the system can create a safe environment through the use of fewer chemicals in production, i.e. safe products for end-users. This system can also promote greater product satisfaction through better quality and longer-lasting products. It can promote well-being and happiness through less materialistic consumption, e.g. by offering experiences through sharing, swapping, lending, updating or do-it-yourself fashion. We can learn to invest in higher quality and more expensive products, use them longer, own less and take good care of our possessions. Furthermore, such a system can mean more social justice and better working conditions for textile factory workers, while through slowing the system, it is possible to increase the end price of the product and invest in

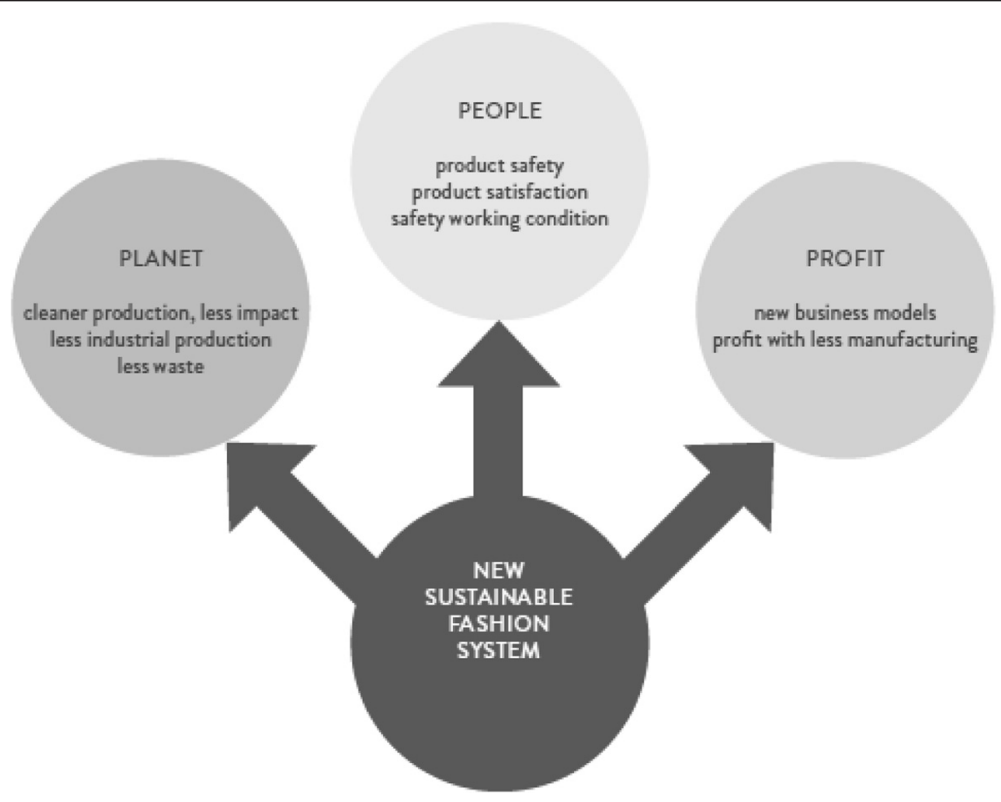

Figure 1 Sustainable fashion system can create value to people, environment and business (Niinimäki, 2013, 35)nn. 
better factories. For the environment, through cleaner production and perhaps even less industrial production and waste, the benefits for slower cycles are clear. For business, new models to make profit in an environmentally beneficial way have to be created. New system thinking and these radical business models can afford new business opportunities through, e.g. a service approach, to encourage less materialistic industrial manufacturing (Niinimäki 2013).

\section{Conclusions}

This text provided an overview for ethics in the sustainable fashion field. It was grounded on environmental ethics and value discussion in it. As Ehrenfeld (2015, 61, based on Rittel and Webber 1973) argues 'solutions for wicked problems are not true-or-false but good-or-bad', which grounds the discussion in sustainable design on ethics, moral and values. Moreover, he points out that each 'implemented solution to a wicked problem has consequences'. Sustainable fashion is a wicked problem: there is no simple truth how to make things better or right, but only different approaches to improve the current situation. Values and ethics are fundamental grounds also for sustainable fashion, and they might help to widen the discussion and seeing problem areas more holistically and further to include the ethical dimension more tightly to discussion. Ethics is the ground for making choices in the sustainable design and manufacturing and even while considering the business models and profit-making options. It is worthwhile to investigate the value base in sustainable fashion and further to consider the consequences of our design and industrial manufacturing processes for the environment, human health and for societies.

Based on environmental ethics, first, we have to consider the system level change, what is right for the ecosystem, societies and community as a whole in the context of sustainable development. Secondly, we should consider the human health issues in production and also in the use situation and the use of chemicals in the textile production. Finally, we have to take into account the sustainable use of resources; emphasising renewable and recyclable materials, considering efficient or sufficient principles and further creating a slower and closed-looksystem for the fashion industry.

Even though ethical consideration might be a complicated and hard task to do for companies, it can open new business possibilities, while consumers are more than ever interested on environmental values. Products have to offer those values that are important to consumers. If the value offering of the new product is an answer to a consumer's value seeking, there is a business opportunity (Niinimäki 2011). If a consumer's deep inner needs are understood, a new sustainable fashion business can be done in a less materialistic way, e.g. offering services to fulfil the need for appearance change instead of new products or offer emotional experiences without purchasing. Moreover, in the future, in a sustainable economy, producers and consumers begin to be partners in co-producing value in a closed loop industrial system where all materials, even old clothes, are valuable raw material for the industrial system.

The values behind the product and company create the foundation upon which a good design is built: a design that is grounded on ethical consideration, which has a low environmental impact and which is also easy to fall in love with. This is the way to do sustainable fashion in the future.

\section{Competing interests}

The author declares that she has no competing interest.

Received: 24 November 2014 Accepted: 3 February 2015

Published online: 20 April 2015

\section{References}

Allwood, JM, Laursen, SEM, de Rodriguez, C, \& Bocken, NMP. (2006). Well dressed? Cambridge, UK: University of Cambridge Institute of Manufacturing.

Armstrong, C., Niinimäki, K., Kujala, S., Karell, E. \& Lang, C. (2015). Sustainable Product-Service Systems for Clothing: Exploring Consumer Perceptions of Consumption Alternatives in Finland. Journal of Cleaner Production (in press).

Belz, FM, \& Peattie, K. (2010). Sustainability marketing. A global perspective. Chichester, UK: John Wiley \& Son.

Belz, F, \& Peattie, K. (2011). Sustainability marketing: a global perspective (3rd ed.). West Sussex, UK: John Wiley \& Sons.

Black, S. (2011). Eco-chic: the fashion paradox. London, UK: Black Dog Publishing. Brezet, H, \& Van Hemel, C. (1997). Ecodesign: a promising approach to sustainable production and consumption. Paris: UNEP.

Clegg, B. (2011). Sustainable business: financial times briefings. Harlow, UK: Pearson education.

Cooper, T. (2005). Slower consumption: reflections on products' life spans and the 'throwaway society'. Journal of Industrial Ecology, 9(1-2), 51-67.

Ehrenfeld, JR. (2015). The real challenge of sustainability. In K Fletcher \& M Tham (Eds.), Routledge handbook of sustainability and fashion (pp. 57-63). New York, USA: Routledge.

Flecther, K. (2015). Other fashion system. In K Fletcher \& M Tham (Eds.), Routledge handbook of sustainability and fashion (pp. 15-24). New York, USA: Routledge.

Fletcher, K. (2008). Sustainable fashion \& textiles: design journeys. London: Earthscan.

Fletcher, K, \& Grose, L. (2012). Fashion \& sustainability: design for change. London, UK: Laurence King Publishing.

Fry, T. (2009). Design futuring: sustainability, ethics and new practice. Oxford: Berg.

Gibbins, J, \& Reimar. (1999). The politics of postmodernity. London, UK: An introduction to contemporary politics and culture.

Goworek, H, Hiller, A, Fisher, T, Cooper, T, \& Woodward, S. (2013). Consumers' attitudes towards sustainable fashion. In M Gardetti \& A Torres (Eds.), Sustainability in fashion and textiles (pp. 377-392). Sheffield, UK: Greenleaf Publishing.

Jackson, T, \& Shaw, D. (2009). Mastering Fashion Marketing. New York, USA: Palgrave Macmillan

Kemp, R. (2008). Transition management for sustainable consumption and production. In A Tukker, M Charter, C Vezzoli, E Stø, \& MM Andersen (Eds.), System innovation for sustainability: perspectives on radical changes to sustainable consumption and production (pp. 369-390). Sheffield, UK: Greenleaf.

Kruger, H, Himmestrup Dahl, E, Hjort, T, \& Planthinn, D. (2012). Guide lines II: a handbook on sustainability in fashion. Copenhagen: Sustainable Solution Design Association, SSDA.

Leiserowitz, AA, Kates, RW, \& Parris, TM. (2006). Sustainability values, attitudes, and behaviors: a review of multinational and global trends. Annual Review, Environment and Resources, 31, 413-444. http://environment.yale.edu/climatecommunication/files/AttitudesSustainDevelop.pdf (Accessed 1 March 2011). 
Light, A, \& Rolston, H, III. (2003). Introduction: ethics and environmental ethics. In A Light \& H Rolston III (Eds.), Environmental ethics. An anthology (pp. 1-11). Oxford, UK: Blackwell Publishing.

Lowitt, E. (2011). The future of value: how sustainability creates value through competitive differentiation. San Francisco: Jossey-Bass.

Manzini, E. (1994). Design, environment and social quality: from "existenzminimum" to "quality maximum". Design Issues, 10(1), 37-43.

Markides, CC. (1997). Strategic innovation. Sloan Management Review. Spring, 1997, 9-23.

Niemelä, M. (2010). Kestävää muotoilua mallintamassa. Tulkitseva käsitetutkimus taideteollisen muotoilun näkökulmasta. [modeling sustainable design. Interpretative concept research from the viewpoint of craft design]. doctoral dissertation. Helsinki. Finland: University of Art and Design Helsinki.

Niinimäki, K, \& Aakko, M. (2014). Creative control in sustainable fashion. 19th $A D M C$, academic design management conference, design management in the era of disruption. 2-4 September 2014 (pp. 583-600). London, UK: UAL.

Niinimäki, K. (2011). From disposable to sustainable: the complex interplay between design and consumption of textiles and clothing. Doctoral dissertation. Helsinki: Aalto University. https://aaltodoc.aalto.fi/handle/123456789/13770 (Accessed 1 October 2014).

Niinimäki, K (Ed.). (2013). Sustainable fashion: new approaches. Helsinki: Aalto ARTS Books. https://aaltodoc.aalto.fi/handle/123456789/13769(Accessed 1 October 2014).

Niinimäki, K. (2014). Sustainable consumer satisfaction in the context of clothing. In C Vezzoli, C Kohtala, \& A Srinivasan (Eds.), Product-service system design for sustainability (pp. 218-237). Sheffield, UK: Greenleaf.

Ottoman, JA. (2011). The new rules of green marketing: strategies, tools, and inspiration for sustainable branding. Sheffield, UK: Greenleaf.

Paehike, RC. (2000). Environmental values and public policy. In NJ Vig \& ME Kraft (Eds.), Environmental Policy (4th ed., pp. 77-97). Washington, USA: CQ Press.

Palmer, C. (2003). An overview of environmental ethics. In A Light \& H Rolston II (Eds.), Environmental ethics. An Anthology (pp. 15-37). Oxford, UK: Blackwell Publishing

Papanek, V. (1995). The green imperative. Ecology and ethics in design and architecture. London: Thames and Hudson.

Park, P, \& Tahara, K. (2008). Quantifying producer and consumer-based eco-efficiencies for the identification of key ecodesign issues. Journal of Cleaner Production, $16,95-104$.

Porter, ME, \& Kramer, MR. (2006). Strategy and society; the link between competitive advantage and corporate social responsibility. Harvard business review, 84(12), 78-92. 163

Scherer, D. (2003). The ethics of sustainable resources. In A Light \& H Rolston III (Eds.), Environmental ethics. An Anthology (pp. 334-358). Oxford, UK: Blackwell Publishing.

Shove, E, Watson, M, Hand, M, \& Ingram, J. (2007). The design of everyday life Oxford: Berg.

Tischner, U, \& Charter, M. (2001). Sustainable product design. In M Charter \& U Tischner (Eds.), Sustainable solutions: developing products and services for the future (pp. 118-138). Sheffield: Greenleaf.

Tojo, N, Kogg, B, Kiørboe, N, Kjær, B, \& Aalto, K. (2012). Prevention of textile waste: material flows of textile in three Nordic countries and suggestions on policy instruments. Copenhagen: Nordic Council of Ministers.

Tukker, A, Emmert, S, Charter, M, Vezzoli, C, Stø, E, Andersen, MM, et al. (2008). Fostering change to sustainable consumption and production: an evidence based view. Journal of Cleaner Production, 16, 1218-1225

van Dyk, L. (2008). Developing strategies for a typology of sustainable fashion design. In J Hethorn \& C Ulasewicz (Eds.), Sustainable fashion. Why now? (pp. 233-263). New York: Fairchild Books.

Verganti, R. (2009). Design driven innovation: changing the rules of competition by radically innovating what things mean. Boston, USA: Harvard Business Press.

Vezzoli, C. (2007). System design for sustainability. Theory, methods and tools for a sustainable "satisfaction-system" design. Milan: Maggioli Editore.

Walker, S. (2007). Sustainable by design. Exploration in theory and practice. London, UK: Earthscan.

\section{Submit your manuscript to a SpringerOpen ${ }^{\odot}$ journal and benefit from:}

- Convenient online submission

- Rigorous peer review

- Immediate publication on acceptance

- Open access: articles freely available online

- High visibility within the field

- Retaining the copyright to your article

Submit your next manuscript at $>$ springeropen.com 